\title{
PENGARUH PENGGUNAAN DIAGRAM ROUNDHOUSE TERHADAP KETERAMPILAN METAKOGNISI SISWA
}

\section{Wakhidatul Hardiyanti ${ }^{1 *}$, Yunin Hidayati ${ }^{2}$, Wiwin Puspita Hadi ${ }^{3}$, Irsad Rosidi ${ }^{4}$}

\author{
Universitas Trunojoyo Madura1, 2, 3, 4 \\ *Corresponding Author: wakhidatulhardiyanti@gmail.com
}

DOI: $10.24929 /$ lens.v11i1.119

\begin{abstract}
ABSTRAK
Penelitian ini bertujuan untuk mengetahui pengaruh penggunaan strategi diagram roundhouse terhadap keterampilan metakognisi siswa. Jenis penelitian adalah quasi experiment dengan desain one group pretest-posttest design. Populasi penelitian adalah semua siswa kelas VII di SMPN 1 Pungging Mojokerto tahun ajaran 2019/2020 dan sampel penelitian pada kelas VII-H. Instrumen pengambilan data menggunakan tes MSI (metacognitive skills inventory) sebanyak 10 soal essay untuk mengetahui keterampilan metakognisi siswa. Hasil penelitian menunjukkan bahwa rata-rata posttest MSI sebesar 70.0 dengan kategori tinggi. Pengujian hipotesis menggunakan uji t berpasangan. Hasil uji hipotesis menunjukkan $t_{\text {hitung }}$ sebesar 18.595 dan $t_{\text {tabel }}$ sebesar 2.04523 maka $t_{\text {hitung }}>t_{\text {tabel }}(18.595>2.04523)$. Berdasarkan hasil yang diperoleh dapat disimpulkan bahwa penggunaan strategi diagram roundhouse berpengaruh terhadap keterampilan metakognisi siswa.
\end{abstract}

Keywords: Diagram Roundhouse, Keterampilan Metakognisi, Metacognitive Skills Inventory

\section{ABSTRACT}

The study aims to determine the effect of roundhouse strategy on students' metacognition skills. This type of research is quasi experiment with one group pretest-posttest design. the population is all of the student in sevent grade event at SMPN 1 Pungging Mojokerto even 2019/2020 and the sample is VII-H class. Data collection instrument using a MSI (metacognitive skills inventory) test as many as 10 essay questions to know the students' metacognition skills. The result of the research showed that the average of MSI posttest is 70.0 which shows high category. Testing the hypothesis of the research is paired t-test. The result of hypothesis test showed a $t_{\text {value }}$ is 18.595 and $t_{\text {table }}$ is 2.04523 then $t_{\text {value }}>t_{\text {table }}$ (18.595 > 2.04523). Based on the research result it can be concluded that used roundhouse strategy is an influence on students' metacogition skills.

Keywords : Roundhouse Diagram, Metacognition Skills, Metacognitive Skills Inventory

\section{PENDAHULUAN}

Pendidikan sangat berperan dalam meningkatkan potensi dan kemampuan siswa melalui proses belajar. Namun kenyataannya, pembelajaran masih secara konvensional, sehingga membuat siswa menjadi pasif selama proses pembelajaran. Hal tersebut dapat membuat siswa tidak memiliki keterampilan yang memadai terutama dalam mengaplikasikan ilmunya dalam kehidupan sehari-hari (Anggraini, Syachruddin, \& Ramdani, 2020). Terutama dalam pembelajaran IPA, siswa dilatih untuk mempelajari alam secara langsung dan mampu melibatkan diri dalam aktivitas yang berhubungan dengan alam (Rizkita, dkk, 2016). Melibatkan siswa secara aktif selama pembelajaran IPA dapat membantu siswa untuk mengembangkan kreativitas serta mampu menentukan sendiri strategi belajar yang akan digunakannya, sehingga metakognisi siswa akan meningkat (Dewi, Ardana, \& Sariyasa, 2019).

Pengetahuan siswa sangat ditentukan oleh proses kognitif saat pembelajaran yang disebut keterampilan metakognisi. Metakognisi menurut Ozturk (2017) digambarkan sebagai kesadaran diri seseorang terhadap pemikiran dan pengaturan 
diri selama proses kognitif. Keterampilan metakognisi sangat diperlukan dalam mencapai kesuksesan belajar, karena keterampilan tersebut akan memungkinkan siswa dalam mengelola proses kognitif serta mampu menemukan kelemahan yang akan diperbaiki pada proses berpikir berikutnya (Suendarti \& Liberna, 2018). Metakognisi ditekankan sebagai kemampuan dalam memantau dan memahami aktivitas berpikir, sehingga proses metakognisi setiap individu akan berbeda sesuai kemampuannya (Thayeb \& Putri, 2017).

Komponen utama metakognisi menurut Jahangard, Soltani, \& Alinejad (2016) terdiri atas dua komponen utama, yakni knowledge of cognition (pengetahuan metakognisi) dan regulation of cognition (regulasi metakognisi). Pengetahuan metakognisi berkaitan tentang keterampilan dan bagaimana keterampilan tersebut digunakan, terdiri dari tiga indikator yaitu pengetahuan deklaratif, prosedural, dan kondisional. Sedangkan komponen regulasi metakognisi berkaitan dengan aktivitas siswa dalam mengontrol proses berpikir, terbagi menjadi lima indikator yaitu perencanaan, manajemen pengelolaan informasi, pemantauan, strategi koreksi, dan evaluasi (Barida, 2017).

Selain siswa diharapkan mampu memahami konsep IPA dengan baik, siswa juga dibimbing untuk menerapkan konsep IPA dalam menjelaskan gejala alam yang terjadi disekitarnya dan pembelajaran tidak terfokus pada hafalan saja. Siswa mempunyai rentang ingatan yang terbatas, informasi yang diterima akan dibatasi kemudian diproses dan diingat kembali (Herpratiwi, 2016). Melalui pemberian stimulus berupa chunk (unit dasar dalam ingatan jangka pendek) akan mempermudah siswa dalam pemprosesan informasi sesuai teori belajar sibernetik Landa bahwa belajar sebagai pemprosesan informasi dan siswa sebagai pengolah informasi yang akan dipelajari, pemikir, dan pencipta (Ward \& Lee, 2006). Sehingga strategi belajar yang dapat melatih keterampilan metakognitif siswa adalah strategi diagram roundhouse.

Strategi diagram roundhouse menurut Kusumaningrum, Lisdiana, \& Raharjo (2015) merupakan strategi kontrusktivisme yang melibatkan proses analisis konten, perubahan kognitif, dan aplikasi pembelajaran. Diagram roundhouse dapat memudahkan siswa untuk memahami konsep abstrak menjadi konkret serta digunakan untuk mengetahui tingkatan pemahaman siswa pada materi yang dipelajari (Alebous, 2019). Pengetahuan yang diperoleh siswa disusun dalam sebuah diagram melingkar dengan simbol verbal dan visual yang akan memudahkan siswa dalam memorizing dan recalling informasi.

Proses pembelajaran dengan model pembelajaran ICARE dengan strategi diagram roundhouse dihadapkan serta dikaitkan dengan fenomena dalam kehidupan sehari-hari. Hal tersebut sesuai dengan empat unsur utama dalam pembelajaran IPA yaitu : 1) sikap: memunculkan rasa ingin tahu, jujur, teliti, serta menghubungkan sebab akibat, 2) Proses: mampu memecahkan masalah yang sistematis dengan di tunjukkan lewat kerja ilmiah, 3) Produk: sebagai produk yang menghasilkan fakta, prinsip, dan teori, 4) Aplikasi: mampu mengaplikasikan dalam kehidupan sehari-hari (Asih, 2014). Selama proses pembelajaran IPA, keempat unsur tersebut diharapkan muncul supaya siswa mendapatkan pembelajaran yang utuh dan dapat memahami fenomena alam melalui kegiatan belajar. Kegiatan belajar sesuai dengan empat unsur utama dalam pembelajaran IPA dapat melalui kegiatan pemecahan masalah, metode ilmiah, dan meniru cara ilmuwan bekerja dalam menemukan fakta baru (Nufus, dkk. 2017).

Berawal dari sikap rasa ingin tahu siswa tentang seluruh fenomena alam dan masalahnya, kemudian memotivasi siswa untuk melakukan pengamatan empiris sebagai wujud pemberian pengalaman yang secara langsung dialami sendiri oleh siswa melalui proses ilmiah seperti hipotesis, eksperimen, evaluasi, dan kesimpulan. Sikap dan proses ini sebagai upaya mengembangkan keterampilan proses siswa. produknya dapat berupa fakta, prinsip, teori, dan hukum (Sikumbang, 2020).

Berdasarkan hal tersebut, maka dilakukan penelitian berjudul pengaruh penggunaan strategi diagram roundhouse terhadap keterampilan metakognisi siswa. 
penelitian ini bertujuan untuk mengetahui pengaruh penggunaan strategi diagram roundhouse terhadap keterampilan metakognisi pada siswa.

\section{METODE PENELITIAN}

Penelitian ini merupakan penelitian kuantitatif dengan jenis penelitian adalah quasi experiment. Desain penelitian ini adalah one group pretest-posttest design. Penelitian ini dilakukan di SMPN 1 Pungging Mojokerto pada semester genap tahun ajaran 2019/2020. Populasi penelitian ini adalah seluruh siswa kelas VII di SMPN 1 Pungging. Sampel yang digunakan adalah kelas VII-H ditentukan dengan teknik purposive sampling. variabel dalam penelitian ini adalah variabel bebas dan variabel terikat. Variabel bebas dalam penelitian ini adalah strategi diagram roundhouse, sedangkan variabel terikat adalah keterampilan metakognisi siswa.

Teknik pengumpulan data penelitian ini menggunakan tes soal MSI (metacognitive skills inventory) untuk mengukur tingkat keterampilan metakognisi siswa. Tes berjumlah 10 soal esai sesuai tingkatan kognitif taksonomi Bloom yang dipadukan dengan indikator keterampilan metakognisi. Data tes MSI dianalisis menggunakan rumus Sugiyono (2017) sebagai berikut :

Keterangan :

$$
\mathrm{R}=\frac{\mathrm{S}}{\mathrm{N}} \times 100
$$

$\mathrm{R}=$ rata-rata skor

$\mathrm{S}=$ skor yang diperoleh

$\mathrm{N}=$ skor maksimal

Adapun kategori hasil tes MSI menurut Riduwan (2016) pada tabel 1 sebagai berikut:

Tabel 1. Kategori hasil tes MSI

\begin{tabular}{|c|c|}
\hline Nilai & Kategori \\
\hline $80 \leq x \leq 100$ & Sangat tinggi \\
\hline $60 \leq x<80$ & Tinggi \\
\hline $40 \leq x<60$ & Sedang \\
\hline $20 \leq x<40$ & Rendah \\
\hline $0 \leq x<20$ & Sangat rendah \\
\hline
\end{tabular}

Uji prasyarat analisis pada penelitian ini menggunakan uji t berpasangan dengan program SPSS versi 18. Sebelum dilakukan uji hipotesis, perlu dilakukan uji normalitas untuk mengetahui distribusi data yang diperoleh berdistribusi normal atau tidak (Badria, Fajarianingtyas \& Wati, 2020). Uji normalitas penelitian ini menggunakan uji normalitas Shapiro-Wilk dengan taraf signifikansi sebesar $5 \%$.

\section{HASIL DAN PEMBAHASAN}

Keterampilan metakognisi brasal dari siswa melalui aktivitas metakognisi yang membantu mengontrol pemikiran siswa saat belajar. Proses kognisi siswa didukung oleh keterampilan metakognisi yang baik (Suendarti \& Liberna, 2018). Semakin baik keterampilan metakognisi siswa, maka semakin bagus pula hasil belajarnya. Memasukkan aspek-aspek metakognitif ke dalam kegiatan pembelajaran menggunakan strategi diagram roundhouse dapat melibatkan siswa secara aktif dalam proses pembelajaran terutama dalam memahami konsep-konsep baru. Proses kognisi dalam belajar didasarkan pada pemahaman dan pengalaman sebelumnya (Asy'ari, dkk, 2016). Sehingga belajar tidak harus menghafal tetapi lebih menekankan pada pemahaman.

Kelas VII-H diberikan pretest MSI terlebih dahulu untuk mengetahui metakognisi siswa sebelum diberikan perlakukan menggunakan strategi diagram roundhouse. Rata-rata hasil pretest MSI yang diperoleh sebesar 28.1 dengan kategori rendah. Hasil rata-rata yang rendah disebabkan karena siswa belum diajarkan mengenai materi ekosistem dan belum diberikan perlakuan.

Setelah kelas diberi perlakuan dengan menggunakan strategi diagram roundhouse, siswa diberikan posttest untuk mengetahui apakah terdapat pengaruh perlakuan yang sudah diberikan pada materi ekosistem. Rata-rata hasil posttest MSI 
sebesar 70.0 dengan kategori tinggi. Hasil posttest lebih tinggi daripada pretest karena perlakuan yang diberikan dapat membantu siswa dalam melatih keterampilan metakognisi mereka. Rata-rata persentase hasil tes MSI untuk tiap indikator keterampilan metakognisi terdapat pada gambar 1 .

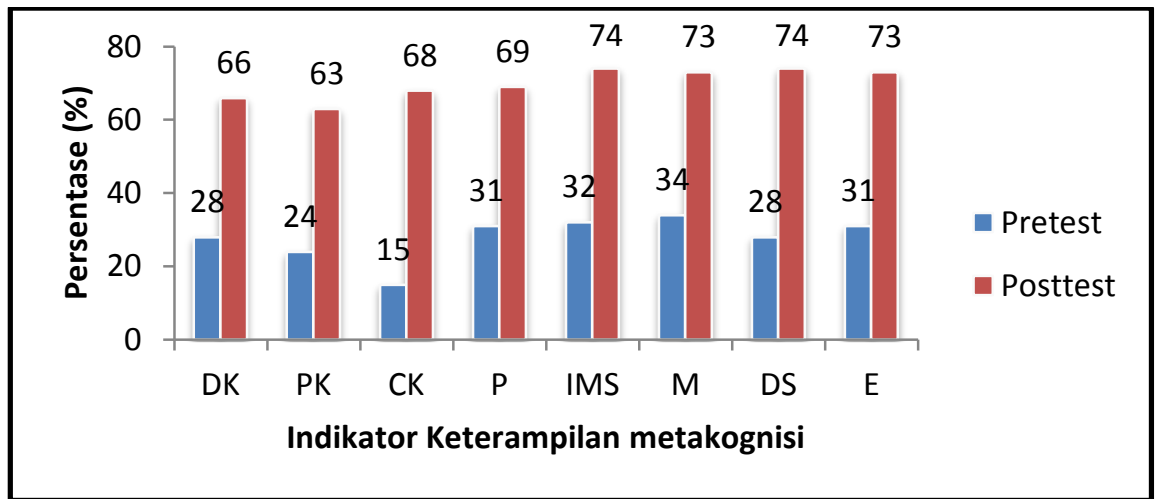

Gambar 1. Persentase Hasil Tes MSI Tiap Indikator Keterampilan Metakognisi

Komponen knowledge of cognition terbagi menjadi tiga indikator yaitu pengetahuan deklaratif (DK), pengetahuan prosedural (PK), dan pengetahuan kondisional (CK). Hasil persentase Pretest MSI menunjukkan keterampilan metakognisi tidak mencapai 50\%. Hal tersebut karena keterampilan metakognisi siswa belum terlatih dengan aktivitas metakognisi. Materi belum disampaikan dan siswa kurang memahami soal yang berkaitan dengan keterampilan metaognitif. Soal metakognitif jarang sekali dipakai guru sehingga membuat siswa belum terbiasa dan kurang menyadari metakognitifnya. Metakognitif dapat berupa pengetahuan dan keterampilan yang dapat diajarkan, dilatih serta dikembangkan pada siswa (Sudjana, 2018).

Pengetahuan kondisional memperoleh persentase posttest MSI tertinggi sebesar $68 \%$. Hal tersebut menunjukkan bahwa siswa tahu bagaimana menggunakan strategi dalam menyelesaikan soal (Pujiank, Jamaluddin, \& Hadipayitno, 2016). Model pembelajaran ICARE memiliki tahapan application dan reflection dikaitkan dengan tahapan diagram roundhouse yaitu diagram dan reflect yang membantu siswa lebih mudah mengkaitkan materi dengan kehidupan sehari-hari melalui diagram roundhouse serta mampu melatih keterampilan metakognitif siswa. Sesuai pendapat bahwa tahapan diagram dan reflect pada strategi diagram roundhouse dapat memperkuat kemampuan dalam menemukan pengetahuan baru dalam pembelajaran berbasis sains (Kusumaningrum, 2015).

Komponen regulation of cognition terbagi menjadi 5 indikator yaitu perencanaan $(P)$, manajemen pengelolaan informasi (IMS), pemantauan (M), strategi koreksi (DS), dan evaluasi (E). Persentase tertinggi terdapat pada indikator manajemen pengelolaan informasi dan strategi koreksi memperoleh persentase sebesar $74 \%$. Berdasarkan kedua indikator tersebut menunjukkan bahwa siswa mampu mengelola informasi yang berhubungan dengan aktivitas belajarnya menggunakan strategi yang sesuai misalnya pengorganisasian dan meringkas (Pujiank, Jamaluddin, \& Hadipayitno, 2016).

Diagram roundhouse dibuat oleh siswa secara berkelompok dan topiknya disesuaikan dengan topik yang sedang dibahas tiap pertemuannya. Setiap kelompok memiliki kreativitas masing-masing dalam memberikan gambar. Hal tersebut berkaitan dengan teori self regulated learning Zimmerman tentang bagaimana siswa mengendalikan pikiran, perilaku, serta emosinya dalam mencapai kesuksesan selama proses belajar (Sari, 2019). Hasil diagram roundhouse dengan topik komponen ekosistem dapat dilihat pada gambar 2 . 


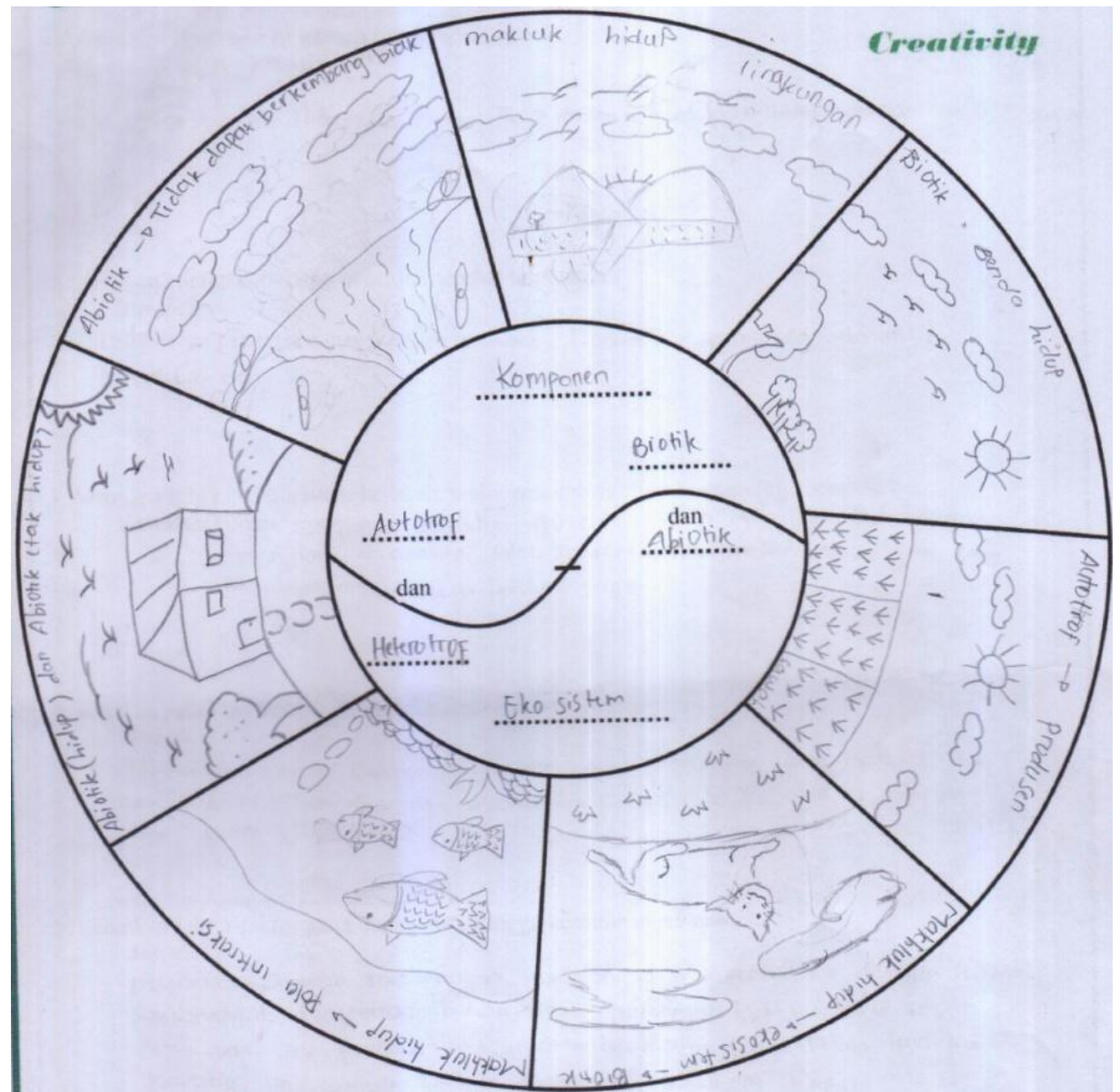

Gambar 2. Diagram roundhouse topik komponen ekosistem

Berdasarkan gambar 2, setiap juring berisi konsep-konsep yang berhubungan dengan topik. Gambar yang dibuat siswa adalah bentuk ekosistem dalam lingkungan seperti ekosistem sawah dan ekosistem perairan. Gambar-gambar tersebut menunjukkan bahwa ekosistem dapat terbentuk karena adanya komponen-komponen seperti yang ditulis pada subtopik. Sesuai dengan pendapat bahwa ekosistem disusun oleh dua komponen utama yaitu biotik dan abiotik. Komponen biotik berdasarkan peranannya dibagi menjadi tiga yaitu autotrof, heterotrof, dan detrivor (Chaniago, 2016).

Indikator keterampilan metakognisi yang muncul pada gambar 2 adalah pengetahuan prosedural dan manajemen pengelolaan informasi. Hal tersebut terlihat selama proses pembuatan diagram roundhouse yang terstruktur dan kesesuaian gambar dengan chunk. Sehingga menunjukkan bahwa siswa mampu menggunakan dan mengorganisasikan strategi yang digunakan selama pemprosesan informasi (Sikumbang, Lengkana, \& Foorantika, 2020).

Pertemuan kedua membahas tentang rantai makanan. Gambar diagram roundhouse pertemuan kedua dapat dilihat pada gambar 3. siswa menuliskan (produsen dan konsumen) dan (dekomposer dan detrivor) sebagai subtopik. kata kunci (chunk) yang ditulis siswa juga berkaitan dengan topik, namun terdapat dua juring yang memiliki konsep sama yaitu tentang pengurai terdiri dari dekomposer dan detrivor. 


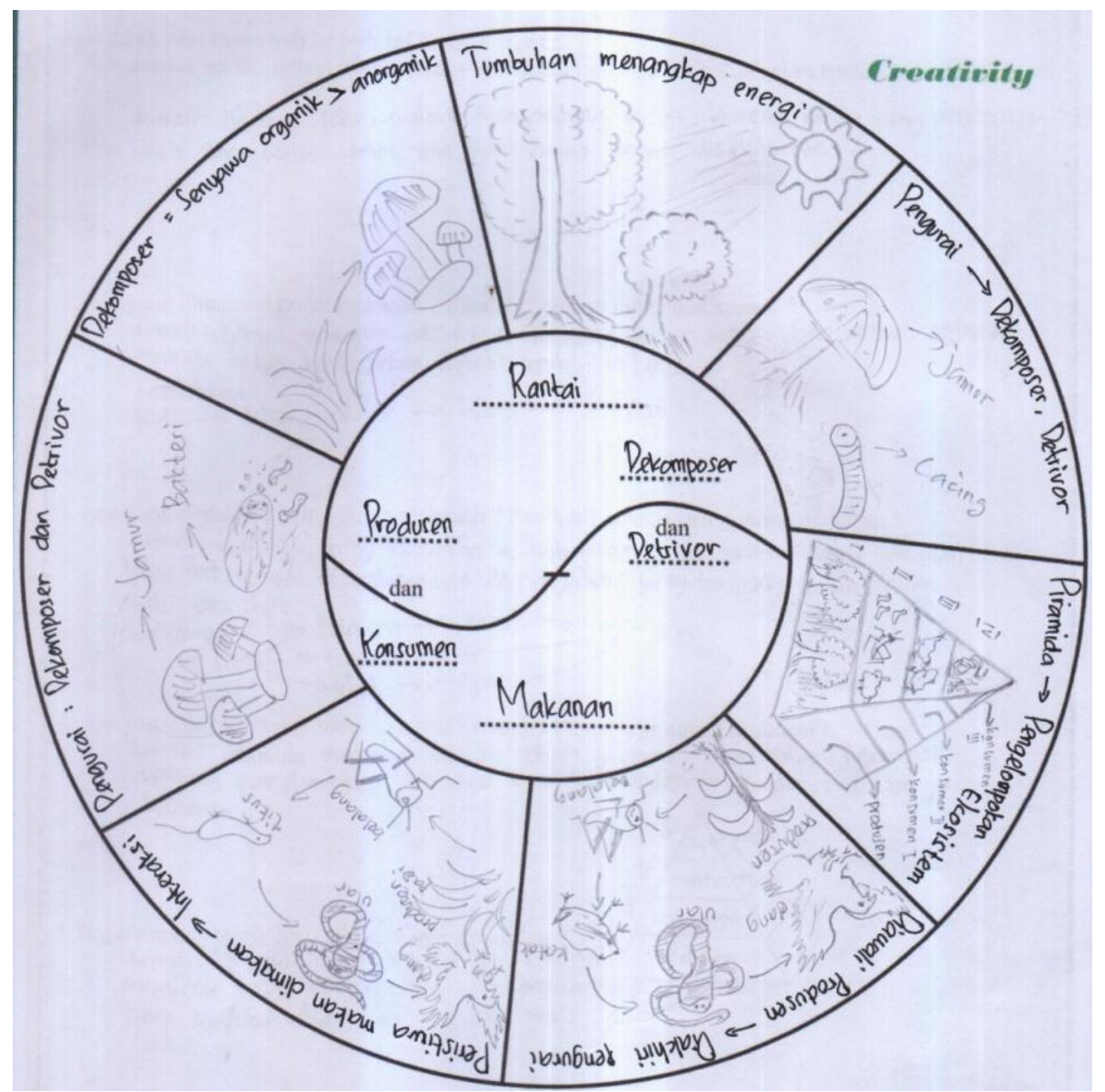

Gambar 3. Diagram roundhouse topik rantai makanan

Menurut pemahaman siswa, rantai makanan merupakan pengalihan energi dari produsen berbantuan cahaya matahari menuju konsumen, dan makhluk hidup yang mati akan diuraikan oleh pengurai (dekomposer dan detrivor). Sesuai pendapat bahwa komunitas tumbuhan dimakan, maka energi tersebut akan diteruskan ke heterotrof yang keberadaanya bergantung pada energi tersebut (Kimball, 1983). Indikator information management skills yang cenderung nampak karena siswa mampu mengorganisasi strategi dengan baik.

Terdapat ketidaksesuaian chunk dengan topik utama pada salah satu juring dituliskan piramida (pengelompokan ekosistem). Piramida makanan menggambarkan sebuah interaksi antar komponen biotik lebih dari sekedar suatu peristiwa makan dan dimakan dalam sebuah rantai makanan (Jahidin, 2018). Rantai makanan merupakan peristiwa makan dan dimakan, sementara piramida makanan menunjukkan suatu jumlah organisme dalam tingkat trofik suatu ekosistem (Chaniago, 2016). Hal tersebut menunjukkan bahwa siswa belum mengecek strategi yang telah digunakan dalam pemprosesan informasi. Sehingga indikator monitoring belum terlaksana dengan baik. Monitoring sangat diperlukan untuk menilai sejauh mana keefektivan strategi pembelajaran yang digunakan (Prayogi, 2016). Jika strategi pemprosesan informasi yang digunakan belum sesuai, maka siswa dapat menggunakan strategi lainnya sesuai indikator debugging strategies.

Pertemuan ketiga membahas tentang simbiosis dan dinamika populasi. Gambar diagram roundhouse untuk pertemuan kedua terdapat pada gambar 4 . 


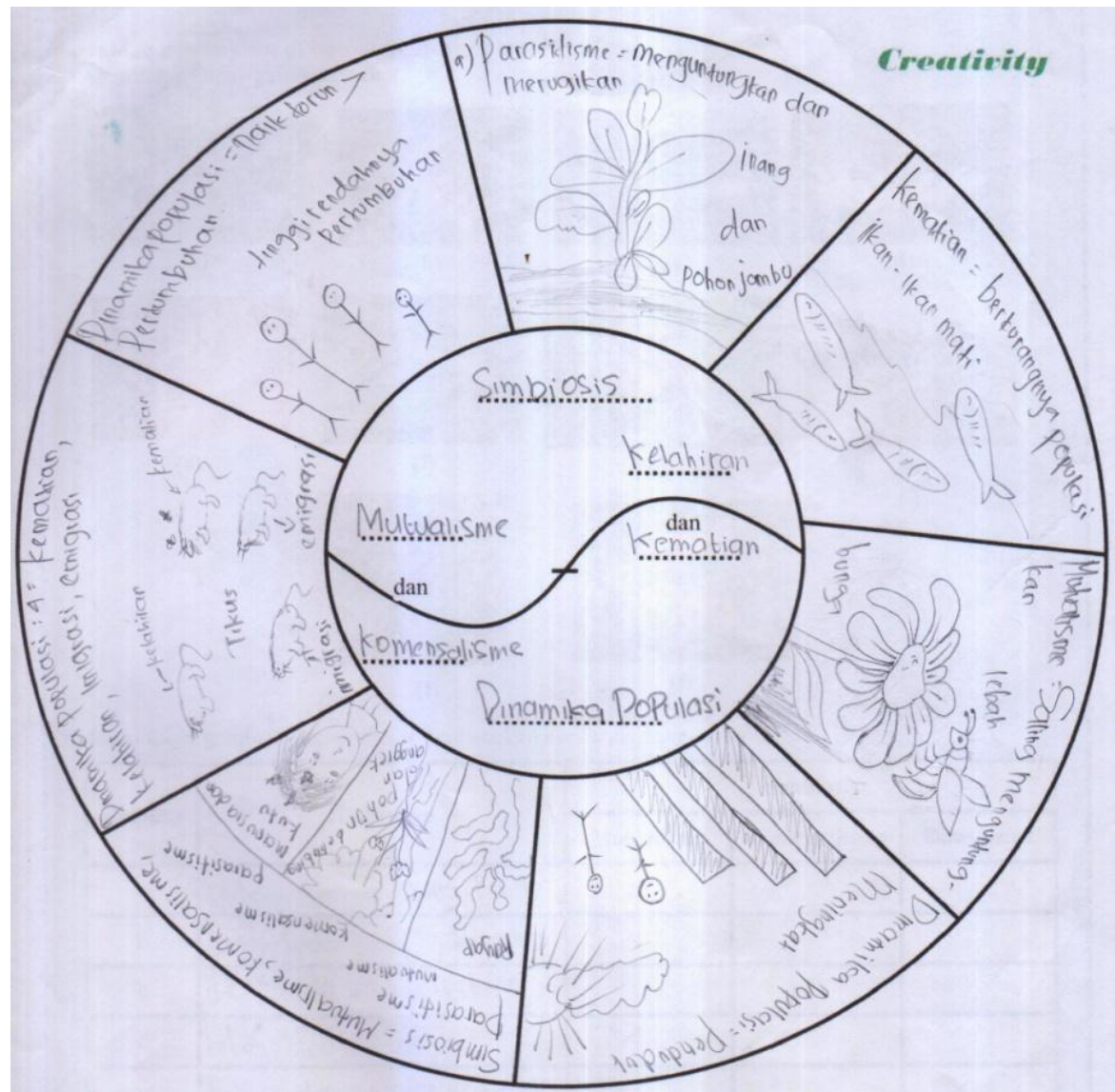

Gambar 4. Diagram roundhouse topik simbiosis dan dinamika populasi

Berdasarkan gambar 4 diagram roundhouse tentang simbiosis dan dinamika populasi dengan subtopik (mutualisme dan komensalisme) dan (kelahiran dan kematian). Menurut pemahaman siswa, simbiosis meliputi mutualisme dan komensalisme merupakan bentuk bentuk interaksi antar makhluk hidup yang berkaitan dengan dinamika populasi yang menimbulkan beberapa hal seperti kepadatan penduduk, kematian, kelahiran, dan imigrasi. Tiap individu selalu berinteraksi dengan individu lain yang sejenis atau lain jenis membentuk suatu pola interaksi disebut simbiosis (Chaniago, 2016). Penambahan terhadap suatu populasi dapat disebabkan oleh penambahan individu lain yang berasal dari daerah lain (imigrasi) dan adanya kelahiran (natalitas), pengurangan suatu populasi dapat disebabkan karena kematian (mortalitas) atau keluarnya suatu individu dari populasi ke wilayah lain (Saputra, 2007).

Indikator keterampilan metakognitif yang muncul pada gambar 4 adalah Procedural knowledge. Hal tersebut terlihat selama proses pembuatan diagram roundhouse yang terstruktur. Sehingga menunjukkan bahwa siswa tahu bagaimana menggunakan strategi dengan baik dan terstruktur (Prayogi, 2016). Namun terdapat gambar dan chunk yang masih belum berkaitan misalnya dinamika populasi = jumlah penduduk meningkat, gambar yang dibuat kurang sesuai dengan chunk. Hal tersebut menunjukkan bahwa indikator information management skills belum dilakukan dengan baik oleh siswa.

Pelatihan pembuatan diagram roundhouse sangat membantu siswa dalam mengingat dan memahami materi yang dipelajari sehingga pengetahuan yang telah didapatkan oleh siswa dapat disimpan lebih lama didalam memori. Jika siswa telah dapat memahami apa yang dipelajari maka siswa dapat lebih mudah merencanakan sesuatu atau membuat suatu visualisasi yang berkaitan dengan pengetahuannya dengan cara mengkombinasikan pengetahuannya. 
Uji hipotesis menggunakan uji t berpasangan yaitu untuk mengetahui pengaruh penggunaan strategi diagram roundhouse terhadap keterampilan metakognisi siswa. Syarat uji t berpasangan yaitu data berdistribusi normal (Bogdanović, 2015). Data terlebih dahulu dilakukan uji normalitas. Hasil uji normalitas menunjukkan bahwa signifikansi $\geq 0.05$ sehingga data berdistribusi normal dan dapat dilanjutkan uji $t$ berpasangan. Berdasarkan hasil uji t berpasangan, diperoleh $t_{\text {hitung }}$ sebesar 18.595 dan $t_{\text {tabel }}$ sebesar 2.04523 maka $t_{\text {hitung }}>t_{\text {tabel }}(18.595>2.04523)$ sehingga disimpulkan bahwa terdapat pengaruh penggunaan strategi diagram roundhouse terhadap keterampilan metakognisi siswa. menurut Wachidah \& Wasis (2015) keterampilan metakognisi yang terlatih dapat membantu pemahaman siswa dalam menyerap pembelajaran sehingga hasil belajar yang diperoleh juga akan maksimal.

Keterampilan metakognisi tidak dapat muncul dengan sendirinya, namun diperlukan latihan sehingga akan menjadi kebiasaan (Thayeb \& Putri, 2017). Pola belajar secara berkelompok juga dapat menimbulkan gagasan yang lebih bermutu dan memotivasi untuk bekerja lebih keras demi keberhasilan mereka (Nurlaili, Afriansyah, \& Nuri, 2017). Interaksi yang terjadi dalam kelompok menjadi faktor terpenting dalam memicu proses kognitif siswa.

\section{KESIMPULAN}

Berdasarkan hasil analisis data sebagaimana telah diuraikan diatas, maka dapat disimpulkan bahwa :

1. Penggunaan strategi diagram roundhouse berpengaruh secara signifikan terhadap keterampilan metakognisi siswa kelas VII di SMPN 1 Pungging Mojokerto tahun ajaran 2019/2020.

2. Indikator manajemen pengelolaan informasi dan strategi koreksi memperoleh persentase tertinggi sebesar $74 \%$.

3. Indikator keterampilan metakognisi yang muncul pada gambar siswa adalah pengetahuan prosedural dan manajemen pengelolaan informasi, sehingga menunjukkan bahwa siswa mampu menggunakan dan mengorganisasikan strategi yang digunakan selama pemprosesan informasi.

\section{SARAN}

Proses pembuatan diagram roundhouse memerlukan waktu yang relatif lama, sehingga guru harus dapat mengatur waktu dengan baik selama proses pembelajaran dengan strategi diagram roundhouse. Siswa juga kesulitan dalam membuat diagram Roundhouse karena masih asing, sehingga guru harus terus membimbing siswa selama pembuatan diagram Roundhouse.

\section{REFERENSI}

Alebous, T. (2019). Impact of Using Roundhouse Diagram and Discrepancy Strategy to Improve Reflective Thinking Skills to Acquire Scientific Concepts by Primary Third Grade Students in Jordan. Modern Applied Science, 13(5), 105-113.

Asy'ari, M., Prayogi, S., Samsuri, T., \& Muhali. (2016). Literatur Reviu tentang Kaitan Berpikir Kritis, Berpikir Kreatif, dan Metakognisi dalam pembelajaran. Prosiding Seminar Nasional Pusat Kajian Pendidikan Sains dan Matematika, 292 - 298. Mataram.

Badria, I. L., Fajarianingtyas, D. A., \& Wati, H. D. (2018). Pengaruh Peran Orang Tua dan Kesiapan Belajar terhadap Prestasi Belajar IPA. Jurnal LENSA (Lentera Sains), 8(1), 19-27.

Barida, M. (2017). Keterampilan Metakognisi Mahasiswa Program Studi Bimbingan dan Konseling terhadap Mata Kuliah Statistik. Jurnal Psikologi Pendidikan \& Konseling, 3(2), 46-54. 
Bogdanović, I., Obadović, D. Ž., Cvjetićanin, S., Segedinac, M., \& Budić, S. (2015). Students' Metacognitive Awareness and Physics Learning Efficiency and Correlation between Them. European Journal Of Physics Education, 6(2), 18-30.

Chaniago, R. (2016). Biologi (Pertama). Yogyakarta: Innosain.

Dewi, N. P. R., Ardana, I. M., \& Sariyasa, S. (2019). Efektivitas Model ICARE Berbantuan Geogebra Untuk Meningkatkan Kemampuan Pemecahan Masalah Matematis Siswa. JNPM (Jurnal Nasional Pendidikan Matematika), 3(1), 109122.

Hakim, A., Jufri, A. W., Bactiar, I., \& Bahri, S. (2020). Kajian Pelaksanaan Praktikum Ilmu Pengetahuan Alam Sekolah Menengah Pertama di Kota Mataram. Jurnal Pijar MIPA, 15(2), 93-98.

Herpratiwi. (2016). Teori Belajar dan Pembelajaran (pertama). Bandar Lampung: Media Akademi.

Jahangard, Z., Soltani, A., \& Alinejad, M. (2016). Exploring the relationship between metacognition and attitudes towards science of senior secondary students through a structural equation modeling analysis. Journal of Baltic Science Education, 15(3), 340-349.

Kusumaningrum, E., Lisdiana, L., \& Raharjo. (2015). Implementasi Strategi Belajar Diagram Roundhouse melalui Cooperative Integrated Reading and Composition (CIRC) pada Materi Daur Biogeokimia. BioaEdu Berkala Ilmiah Pendidikan Biologi, 4(3), 972-977.

Nufus, S. S., Jamaluddin., \& Bachtiar, I. (2017). Pengaruh Pembelajaran Berbasis Multiple Intelligences terhadap Kesadaran Metakognisi dan Hasil Belajaran IPA Biologi Siswa Kelas VIII SMPN 11 Mataram. Jurnal Pijar MIPA, 12(1), 32-38.

Nurlaili., Afriansyah, A., \& Nuri, Y. A. (2017). Pengaruh Model Pembelajaran Challenge Based Learning terhadap Kemampuan Berpikir Kritis Siswa pada Materi Lingkungan Kelas X di SMA Negeri 4 Prabumulih. Jurnal Pena Sains, 4(2), 97104.

Ozturk, N. (2017). Assessing Metacognition: Theory and Practices. International Journal of Assessment Tools in Education, 4(2), 134-148.

Permana, H. P., \& Setyawan, D. (2019). Implementasi Mind Mapping melalui Project Based Learning untuk Meningkatkan Kemampuan Berpikir Kritis dan Hasil Belajar. Jurnal Pijar MIPA, 14(1), 50-54.

Pujiank, S., Jamaluddin., \& Hadiprayitno, G. (2016). Kemampuan Metakognisi mahasiswa Program Studi pendidikan Biologi FKIP Universitas Mataram. Jurnal Penelitian : Teori, Penelitian, dan Pengembangan, 1(10), 2016-2022.

Riduwan. (2016). Skala Pengukuran Variabel-Variabel Penelitian. Bandung: Alfabeta.

Rizkita, L., Suwono, H., \& Susilo, H. (2016). Pengaruh Pembelajaran Socio-Scientific Problem-Based Learning terhadap Keterampilan Metakognitif dan Hasil Belajar Kognitif Siswa Kelas X SMAN Kota Malang. Jurnal Pendidikan : Teori, Peneltian, Dan Pengembangan, 1(4), 732-738.

Sari, D. A. W. (2019). Pengaruh Model Problem Based Learning disertai Diagram Roundhouse terhadap Kemampuan Pemecahan Masalah Peserta Didik X pada 
Mata Pelajaran Biologi Materi Protista di SMA Negeri 16 Bandar Lampung. Skripsi Pendidikan Biologi, Program SarjanaUniversitas Islam Negeri Raden Intan Lampung.

Sikumbang, D., Lengkana, D., \& Foorantika, R. (2020). The Effect of Practicum Method on Representation Ability and Cognitive Learning Outcomes. Jurnal Pena Sains, 7(1), 25-32.

Suendarti, M., \& Liberna, H. (2018). The Effect of I-CARE Learning Model on the Students' Metacognition. Journal of Mathematics Education, 3(2), 40-46.

Sugiyono. (2017). Statistika untuk Penelitian. Bandung: Alfabeta.

Thayeb, T., \& Putri, A. P. (2017). Kemampuan Metakognisi untuk Meningkatkan Keterampilan Pemecahan Masalah Matematika Siswa Kelas VIII B Mts Madani Alauddin Paopao Kabupaten Gowa. MaPan, 5(1), 1-17.

Wachidah, U., \& Wasis. (2015). Penerapan Strategi Mind mapping Untuk Meningkatkan Keterampilan Metakognitif Siswa Pada Materi Alat-Alat. Jurnal Inovasi Pendidikan Fisika (JIFF), 04(02), 33-39.

Ward, R. E., \& Lee, W. D. (2006). Understanding the Periodic Table of Elements via Iconic Mapping and Sequential Diagramming: The Roundhouse Strategy. Science Activities: Classroom Projects and Curriculum Ideas, 42(4), 11-19. 